\title{
Część II
}

\section{BADANIA JAKOŚCIOWE}





\section{Katarzyna Karpińska-Szaj UAM Poznań \\ DIALOG W METODZIE INDYWIDUALNYCH PRZYPADKÓW}

\section{Dialogue in individual case study methodology}

An individual case study is a research procedure and at the same time a practical approach which makes it possible to apply a variety of data gathering instruments. One such instrument is dialogue, which is described in this article as a tool meant for the diagnosis and treatment of difficulties in foreign language learning as experienced by students with special educational needs who have disturbed development in their native language.

Należąca do metod biograficznych, metoda indywidualnych przypadków (tzw. studium przypadku) ma na celu z jednej strony zbieranie danych odnośnie analizowanej, pojedynczej i wyjątkowej w swojej specyfice sytuacji uczenia się (cele badawcze służące opisowi lub/i diagnozowaniu danego zjawiska) a z drugiej strony, prześledzenie przebiegu i skuteczności proponowanych działań dydaktycznych (np. w celach terapeutycznych, remediacyjnych) w określonej sytuacji edukacyjnej. Metoda indywidualnych przypadków jest więc zarówno postępowaniem badawczym jak i podejściem praktycznym, w którym możliwe jest zastosowanie różnych instrumentów zbierania danych. Jednym z takich instrumentów jest dialog, który w artykule zostanie opisany jako narzędzie służące diagnozowaniu i remediacji trudności w sytuacji nauki języka obcego przez uczniów o specjalnych potrzebach edukacyjnych związanych z zaburzonym rozwojem języka ojczystego. Aby zilustrować wartość terapeutyczną tego narzędzia, przedstawię najpierw korzyści i ewentualne niedostatki metody indywidualnych przypadków w nauczaniu języka obcego, a następnie postaram się wykazać przydatność dialogu w rozwijaniu kompetencji poznawczej ucznia kształtującej się dzięki nabywanej sprawności językowej. 


\section{Perspektywa badawcza i dydaktyczno-terapeutyczna metody in- dywidualnych przypadków}

W pedagogice metodę indywidualnych przypadków stosuje się zazwyczaj w sytuacji wyjątkowej, nietypowej, specyficznej w swej naturze. Oznacza to, że badaniami za pomocą tej metody obejmuje się głównie osoby, które w konkretnej sytuacji uczenia się prezentują zaburzony, nieharmonijny rozwój lub przeciwnie, nadzwyczajnie szybki, skokowy, wybitny postęp. Studium przypadku nie powinno zatem obejmować sytuacji częstych, opisanych i syntetycznie ujętych jako norma poznawcza (wyjątkiem jest dobór przykładów ilustrujących funkcjonowanie sytuacji rutynowych lub modelowych). Celem badawczym metody indywidualnych przypadków jest przede wszystkim adekwatne postawienie diagnozy nietypowego zachowania (np. trudności w uczeniu się) oraz ukazanie ewentualnych przyczyn owego zachowania i możliwości poznawczych badanej osoby.

Metoda indywidualnych przypadków opisywania jest w metodologii badań pedagogicznych jako metoda niesamodzielna. Jest ona ,jedynie osobliwym podejściem czy postępowaniem badawczym, wykorzystującym inne metody i techniki badań. Można powiedzieć, ze nie jest ona żadną konkretną metodą czy technika gromadzenia danych" (Lobocki 2009:305). Owa niesamodzielność wynika z dużej dozy subiektywizmu zawartej w uzyskanych informacjach, wynikających $z$ braku ustalonych wzorców (takich, jak standaryzowana ankieta czy sondaż), a także niekiedy, z trudności pozyskania odpowiednich danych (brak nawiązania odpowiedniego kontaktu z osobą badaną, nieumiejętne prowadzenie wywiadu, stronniczość i tendencyjność w doborze technik i ich zastosowaniu, nadinterpretacja danych itd.). Jednak studium przypadku zyskało dużą popularność jako metoda o wartościach dydaktyczno-terapeutycznych, tj. nie koniecznie poddająca się rygorom metodologicznym (związanych z trafnością i rzetelnością obranych kryteriów pomiaru), ale spełniająca się doskonale jako narzędzie usprawniające działania terapeutyczne w rewalidacji lub/i remediacji trudności w uczeniu się. W takiej sytuacji pełni ona funkcję ilustrującą przyjęta perspektywę prowadzonych działań dydaktycznych/terapeutycznych. Studium przypadku może też stanowić ważną część badania w działaniu, gdyż zakłada otwartość terapeuty/nauczyciela odnośnie koncepcji i sposobów nauczania.

$\mathrm{Na}$ gruncie glottodydaktyki, metoda indywidualnych przypadków stosowania jest głównie w celach diagnozy i egzemplifikacji sposobów rozwijania kompetencji komunikacyjnej w powiązaniu z kompetencją uczenia się. Studium przypadku może dotyczyć sytuacji niestandardowych, ale także może być stosowane w celu wyłonienia cech właściwych danej sytuacji uczenia się lub/i sytuacji komunikacyjnej. Ten rodzaj pozyskiwania danych jest stosowany przede wszystkim w badaniach nad strategiami uczenia się (zob. podsumowanie badań na ten temat w Pawlak 2009). Stosowane narzędzia mają często 
formę narracji, np. protokoły głośnego myślenia, polegające na werbalizowaniu i opisywaniu operacji mentalnych w trakcie wykonywanego zadania (w celu poznania stosowanych strategii), ale także narzędzia dialogowe, interakcyjne. Zakres tych ostatnich wykracza już poza identyfikację strategii i dotyczy udziału świadomości, zmiany postaw, modyfikacji stosowania strategii, itp. Pozyskany model funkcjonowania jednostki nie musi bowiem świadczyć o modelu nabywania danych kompetencji (zob. Gaté 2000). W perspektywie działań dydaktycznych istotne jest zatem połączenie narzędzi monologowych z dialogowymi, gdyż możliwości oddziaływania dydaktycznego zwiększają się zdecydowanie, jeśli nie poprzestaje się na diagnozie (identyfikacji sposobów uczenia się) a uwypukla się wymiar remediacyjny, zmierzający do modyfikacji/ ubogacania sposobów uczenia się.

W dydaktyce językowej metoda indywidualnych przypadków jest ewidentnie przydatna $\mathrm{w}$ sytuacji a priori nietypowej, jaką jest nauczanie języka obcego uczniów z deficytami rozwojowymi czy z trudnościami w uczeniu się implikującymi niedobory języka ojczystego. Pożądanym narzędziem jest tu zdecydowanie dialog, gdyż w większości przypadków priorytet mają cele rewalidacyjne, usprawniające funkcjonowanie ucznia z zaburzoną kompetencją językowa. W następnej części przedstawiam możliwości zastosowania dialogu w pracy indywidualnej z ,nietypowym” uczniem.

\section{Dialog dydaktyczny - różne ujęcia}

We wszystkich swoich zastosowaniach w sytuacji uczenia się obserwowanych w metodzie indywidualnych przypadków, dialog dydaktyczny ma na celu wyłonienie i uświadomienie uczniowi jemu właściwego funkcjonowania poznawczego w rozwijaniu określonych kompetencji. Dzieje się to za pomocą mediacji osoby towarzyszącej: nauczyciela, terapeuty lub rodzica. Nauczyciel/terapeuta zapewnia uczniowi, za pomoca kierowanej rozmowy, odpowiedni wgląd w stosowane dotąd sposoby uczenia się (a także w nawet w sam akt poznawczy, o czym będzie mowa w dalszej części artykułu) oraz ich indywidualne modyfikacje czy ubogacanie. Przyjmując różne formy w zależności od osadzenia w wybranej koncepcji nauczania/uczenia się, dialog może być nakierowany na uchwycenie związków logicznych w formułowaniu myśli/rozwiązywaniu problemów (np. wywiad krytyczny wywodzący się z tradycji piagetowskiej, por. Perraudeau 1998), może też zmierzać do wyjaśniania sposobów uczenia się (por. wywiad wyjaśniajacy Vermersch 1994, 1999), czy wreszcie może docierać do indywidualnych środków poznawczych wyrażonych w specyficznej formie wywołania w umyśle w celu uczenia się (dialog dydaktyczny według metodologii Kierowania umystem Antoina de La Garanderie 1984, 2000). Przytoczone trzy przykłady ujęć interakcji uczeń - nauczyciel/terapeuta nie wyczerpują oczywiście 
wielości proponowanych możliwych modeli metody dialogowej. Dialog jest stosowany także w kształtowaniu myślenia abstrakcyjnego w konstruowaniu pojęć poprzez negocjowanie znaczeń w grupie-klasie w podejściu Britt-Mari Barth (1993), jest również znany w pedagogice różnicowej Philippa Meirieu (2003, 2004)․ Dydaktyczna wartość dialogu/interakcji uczeń - nauczyciel w budowaniu wiedzy uwypuklona jest $\mathrm{w}$ tradycji pedagogiki polskiej przez Urszulę Ostrowską (2000) a także w znaczących programach edukacyjnych zasadzających się na promowaniu narracji w konstruowaniu wiedzy ${ }^{2}$. Ze wszystkich tych tendencji można wyłonić dwie zasadnicze, wywodzące się ze źródeł kognitywizmu i konstruktywizmu (perspektywa badań psychologicznych, ujmujących akt poznawczy jako zespół operacji umysłowych potrzebnych do wykonania danego zadania) oraz ujecie fenomenologiczne (tradycja badań filozoficznych ujmująca teorię poznania bez wstępnych założeń, zmierzająca do interpretacji aktu poznawczego takim, jaki jawi się w swej naturze badanej jednostce). Aby uzasadnić wybór odpowiedniej formy dialogu możliwej do zastosowania w sytuacji nauczania języka obcego uczniów z niedoborami języka ojczystego, postaram się dokonać syntetycznego podsumowania obu tych ujęć uwypuklając zakres mechanizmów poznawczych możliwych do uchwycenia na drodze kierowanej samoobserwacji.

\subsection{Podejście konstruktywistyczne}

W dialogu zwraca się uwagę na elementy (symptomy) świadczące o gotowości do wykonania zadania w zależności od etapu rozwojowego ucznia. Charakter procesów konstruowania wiedzy możliwy jest do oszacowania dzięki osiagniętym celom, efektom działania człowieka (powodzenie lub porażka w wykonywanym zadaniu). Dialog ma na celu identyfikację przyczyn sukcesu lub porażki odnośnie następujących po sobie czynności w sytuacji zadaniowej. Sama specyfika aktu poznawczego pozostaje niemożliwa do uświadomienia (a tym bardziej do zwerbalizowania), gdyż świadomości dostępny jest wyłącznie ewentualny przebieg następujących po sobie procesów mentalnych.

Zdecydowanym ułatwieniem w próbie uświadamiania sposobów konstruowania wiedzy jest negocjowanie znaczeń poprzez przyglądanie się zasadności sposobu myślenia partnera dialogu. Taka interpretacja znaczenia dialogu w rozwijaniu uczenia się umożliwia docenienie po pierwsze, interakcyjnej natury budowania wiedzy/kompetencji, a po drugie, nadaje nową wartość procesowi uczenia się osądzając go nie tylko w sytuacji „tu i teraz” (w konkretnym

${ }^{1}$ Dydaktyka różnic indywidualnych na gruncie polskim została zapoczątkowana przez Tadeusza Lewowickiego (1977).

${ }^{2} \mathrm{Na}$ przykład w podejściu edukacyjnym proponowanym jako eksperyment w Autorskiej Szkole Podstawowej „Żak” w Olsztynie, nauczyciele promują konstruowanie wiedzy poprzez autonarracje, które prowokowane sa podczas dialogu z nauczycielem (zob. Klus-Stańska 2002). 
przypadku rozwiązywania zadania), lecz umożliwiając transfer wiedzy i sprawności na inne sytuacje. Oprócz uznania znaczenia wiedzy deklaratywnej i procesualnej, akcent stawia się na działania warunkujące uczenie się, co z kolei uzasadnia dynamiczną naturę transferu wiedzy i sprawności. Transfer wiedzy i sprawności powinien być bowiem wpisany w samą sytuację uczenia się (tzn. w jej założenia, cele uczenia się), gdyż nieskuteczne jest przyswajanie określonej wiedzy/sprawności, a dopiero w dalszej kolejności ćwiczenie transferu (zob. Tardif 1999; por. także dyskusję nad celowością nauczania strategicznego i treningu potencjału intelektualnego w Lévesque 2000).

\subsection{Podejście fenomenologiczne}

Perspektywa fenomenologiczna dialogu dydaktycznego nie pozostaje w opozycji do koncepcji konstruktywistycznej. Przeciwnie, pozostaje z nią zbieżna w zakresie zasadności odwoływania się do tej formy interakcji w uczeniu się (celem uczenia się jest przede wszystkim metapoznanie) i dynamiki konstruowania wiedzy (zwłaszcza odnośnie natury i warunków transferu wiedzy/umiejętności). Jej filozoficzne korzenie umożliwiaja jednak przyjęcie szerszej perspektywy dla uświadamiania sobie procesów poznawczych. Fenomenologiczne ujecie dialogu uzasadnia wartość dialogu jako instrumentu umożliwiającego nawiązanie swoistej relacji między podmiotem (Ja) a partnerem (Ty - w przeciwieństwie do To - postrzeganego obiektu) (zob. Buber 1992). W dialogu uznaje się podmiotowość partnerów, co wiąże się z zasadami jego prowadzenia: otwartości, partnerstwa, zaangażowania, równości i rzeczowości (Stachlewicz 2003). Zasadność i ,,ideologiczne” podłoże odwoływania się do dialogu w kształtowaniu postaw jednostki nie jest jednak jedyną zaleta omawianego tutaj ujęcia dialogu3 ${ }^{3}$ W kontekście uczenia się, fenomenologiczna interpretacja dialogu polega na uznaniu introspekcji jako narzędzia samopoznania. Za pomoca introspekcji można dotrzeć do samego aktu poznawczego, gdyż wg zwolenników tego podejścia, akt poznawczy na podobieństwo aktu fizycznego ma właściwą danej jednostce formę (słowną/dźwiękową lub wewnętrzny obraz) i treść (wrokowq - wywołane obrazy, stuchowq - uwewnętrznione dźwięki, werbalnq - przetworzona na własne słowa i ruchowq - odczuwaną jako ruch lub imitowaną ruchem) (La Garanderie 1984 i 2000, zob. także Gaté 2000) ${ }^{4}$. Warunkiem uczenia się jest świadome wywołanie w umyśle (fr. évocation mentale,

\footnotetext{
${ }^{3}$ Fenomenologiczne ujęcie dialogu jako narzędzia umożliwiającego rozwój nauczyciela języka obcego - uczestnika badania w działaniu przedstawia Danuta Wiśniewska (2009). Autorka wykazuje przydatność dialogu jako przestrzeni poznawczej umożliwiającej rozwój osobowy i zawodowy nauczyciela poprzez refleksję i ewentualną zmianę postaw.

${ }^{4} \mathrm{~W}$ pedagogice ujęcie fenomenologiczne aktu poznawczego stosowane w metodologii Kierowanie umysłem jest znane przede wszystkim na gruncie francuskojęzycznym i propagowanie przez Międzynarodowy Instytut Kierowania Umysłem (Institut International
} 
La Garanderie 1984) i kierowanie reprezentacjami mentalnymi w konkretnym celu (celem tym są działania poznawcze potrzebne do skutecznego uczenia się: uwaga, zapamiętywanie, rozumienie, refleksja i wyobraźnia twórcza). W akcie poznania jednostka buduje więc znaczenie na podstawie uwewnętrznienia postrzeganej informacji (wywołania w umyśle), a nie zmysłowego odbioru rzeczywistości.

Dialog dydaktyczny ma na celu umożliwienie „odkrycia”, że poznanie może być uchwytne i świadomie kierowane poprzez nadanie mu odpowiedniego (właściwego danej osobie) ukierunkowania (fr. projet de sens). Stąd kluczowym pojęciem jest antycypowanie znaczeń (fr. anticipatopn de sens) i ukierunkowanie na wywołanie w umyśle (dopiero w dalszej kolejności na wykonanie zadania). O efektywności uczenia się decyduje więc wewnętrzna struktura mentalna, którą uczeń antycypuje by nadać w umyśle znaczenie postrzeganym obiektom. W perspektywie badawczej, odwołanie się do introspekcji aktu poznawczego promowane w ujęciu fenomenologicznym, z jednej strony uszczupla obiektywizm danych (wartość uchwyconej empirii pozostaje w dużej mierze w sferze domysłu), ale z drugiej jednak strony, daje uczniowi narzędzie samopoznania na poziomie tworzenia podstaw uczenia się, gdyż umożliwia kontrolę nad własnym funkcjonowaniem poznawczym.

\section{Dialog dydaktyczny w nauczaniu języków obcych uczniów z niedoborami języka ojczystego}

Oprócz zauważalnych w komunikacji niedoborów kompetencji językowej u uczniów z deficytami rozwoju języka ojczystego (np. agramatyzmy, problemy ze zrozumieniem, błędna wymowa), bardzo istotnym i trudnym do rewalidacji jest zaburzony rozwój kompetencji kognitywnej wynikający z różnych deficytów percepcyjnych lub/i rozwojowych (implikuje to zahamowany lub nieharmonijny rozwój funkcji reprezentatywnej języka). Aby dziecko mogło funkcjonować w społeczności językowej, powinno nabyć świadomość istnienia związków między znakami językowymi a klasami obiektów i stanów rzeczy pozajęzykowych, do których owe znaki się odnoszą (konwencje referencji) oraz zależności między znaczeniami jednostek językowych (konwencje semantyczne). Niedobory kompetencji kognitywnej mogą być przyczyną problemów związanych z konceptualizacją i kategoryzowaniem rzeczywistości pozajęzykowej (są to na przykład, błędy podlegające na rozszerzeniu lub zawężeniu znaczenia danego pojęcia, tworzenie powiązań logicznych zbudowanych na cechach uznanych przez rodzimych użytkowników języka za drugorzędne, problemy z kategoryzowaniem stosunków przestrzennych i chronologii wydarzeń, rozumienie metafor itp.) (zob. Karpińska-Szaj 2008 i 2009). W sytuacji niezakłóconego rozwoju kompetencji językowej dziecko próbuje ustalić relacje

de Gestion Mentale, zob. www.iigm.org) oraz przez belgijskie stowarzyszenie logopedów i nauczycieli Initiative et Formation (zob. www.ifbelgique.be). 
między zjawiskami wykorzystując zdobyte w innych dziedzinach doświadczenie (w procesie akwizycji języka przeplataja się zatem działania spostrzeżeniowe, dojrzałość poznawcza i wiedza językowa). Jak zauważa Helena Borowiec (2007: 108-110), ze względu na dopiero kształtujące się doświadczenie, dziecko tworzy relacje niepoprawnie, kojarząc przypadkowe cechy przedmiotów, ustalając fałszywe analogie. Konwencje semantyczne i konwencje referencji są jednak nieustannie ubogacane i modyfikowane głównie na podstawie stałej interakcji z dorosłymi. Dzieci z zaburzona kompetencja poznawcza nie mają możliwości takiej nieustannej modyfikacji związków logicznych gdyż swobodny dostęp do mnogości kontekstów występowania pojęć jest znacznie utrudniony. Właściwie dopiero bliższe poznanie dziecka (przebywanie z nim) umożliwia zidentyfikowanie tych trudności (zawsze indywidualnych, mimo możliwych do określenia ogólnych tendencji zaburzeń funkcji reprezentatywnej języka) $)^{5}$. Skłania to do wyboru metodologii indywidualnych przypadków w pracy z uczniem z niedoborami języka ojczystego oraz do wyboru formy dialogu dydaktycznego (w rewalidacji języka i mowy na gruncie języka ojczystego, ale także na lekcji języka obcego), odpowiednio nakierowanego na takie aspekty funkcjonowania w języku, by umożliwić uczniowi dotarcie do jemu swoistej natury poznania i pokazać możliwości ich rozwijania lub modyfikacji (tworzenia związków miedzy zjawiskiem a reprezentacja językowa). W efekcie dialog dydaktyczny znajduje swoje zastosowanie głównie w terapiach logopedycznych nakierowanych na rozwój poznawczy w użyciu języka ojczystego ${ }^{6}$.

W kontekście nauczania języka obcego dzieci z niedoborami języka ojczystego, dialog dydaktyczny może w znaczny sposób przysłużyć się do budowania osobistej kompetencji komunikacyjnej i ubogacania funkcji poznawczej. Dzieje się to z następujących powodów:

\footnotetext{
${ }^{5}$ Znaczenia przypisywane słowom u dzieci i dorosłych różnią się ze względu na poziom doświadczeń, rozwój poznawczy i stopień opanowania języka. Dzieci i dorośli mimo używania tych samych słów, myślą o przedmiocie, stanie rzeczy lub zjawisku całkiem inaczej (Wygotski 1989:158). Tak, jak w przypadku dzieci w normie rozwojowej można określić etapy i ogólne tendencje kształtowania się konwencji semantycznych i referencji aż do osiagnnięcia kulturowo wspólnych reprezentacji języka w umyśle (zob. podsumowanie badań tego typu w Borowiec 2007), tak w przypadku konkretnych zaburzeń (głuchota, dysfazja, dysleksja rozwojowa i in.), można określić „typowe” trudności z przyswajaniem kategorii referencyjnych i semantycznych. Rozpiętość i wyjątkowość tego typu problemów jest jednak bardzo szeroka i różnorodna, co tym bardziej skłania do indywidualnego traktowania rewalidacji języka i mowy w celu rozwijania reprezentatywnej funkcji języka.

${ }^{6} \mathrm{~W}$ ujęciu prezentowanym przez metodologię Kierowania umystem, dialog dydaktyczny jest przedmiotem zastosowania na gruncie nauczania języka francuskiego jako ojczystego (zob. przykłady zastosowania dialogu dydaktycznego w 18. numerze Femille d'IF (czerwiec 2009, zob. bibliografia) w całości poświęconemu praktyce dialogu w celu rozwijania kompetencji poznawczej uczniów z deficytami języka i mowy).
} 
- poprzez dialog dydaktyczny uczeń może nauczyć się rozpoznawać relacje semantyczne (a przynajmniej nakierowywać uwagę na cechy semantyczne, które do tej pory ignorował - w nauce języka obcego (zwłaszcza w przypadku języka analitycznego, jak język angielski lub język francuski), związki semantyczne są często łatwiej rozpoznawalne (przejrzystość niektórych cech języka obcego sprzyja konceptualizacji/modyfikacji w kształtowaniu pojęć w trakcie nabywania języka ojczystego);

- specyfika nauczania/uczenia się języka obcego często skłania do uświadomienia sobie niedoborów językowych w języku ojczystym, jest też okazją do zapoznania się z możliwościami kompensowania trudności komunikacyjnych jak i poszerzenia wachlarza technik uczenia się języka - w tym zakresie dialog dydaktyczny może być nakierowany na użycie strategii kompensacyjnych;

- transfer wiedzy/sprawności nabywanych w trakcie nauki języka obcego oraz transfer strategii uczenia języka obcego na sytuację przyswajania (rehabilitacji) języka narodowego może zostać wywołany lub/i wzmocniony poprzez dialog dydaktyczny, w którym prowokuje się antycypowanie potencjalnych użyć w obu językach?

\section{Podsumowanie}

„Być może tym, co w istotny sposób odróżnia oba bieguny inteligencji [wybitne uzdolnienia i niepełnosprawność intelektualna - KKS] jest metapoznanie szczególnie dobrze funkcjonujące u zdolnych, a niezbyt skutecznie u niepełnosprawnych. Gdyby tak było, można by podjąć próby zastosowania wiedzy o metapoznawczych aspektach umysłu w celu opracowania skutecznych technik stymulacji i nauczania sprawności intelektualnych" (Brown 1978, Moses i Baird 1999, Nelson 1999 w Nęcka 2003:191). Choć opinia ma formę hipotezy, wydaje się, że dzięki pracy z uczniem opartej na zastosowaniu dialogu dydaktycznego czynności metapoznawcze stają się dla niepełnosprawnego ucznia bliższe, a przynajmniej bardziej „uchwytne”. Proponowane podejście dydaktyczne z użyciem dialogu w przedstawionych tu przypadkach zasadza się bowiem na ukierunkowanej samoobserwacji przebiegu uczenia się języków.

Istotna cechą dialogu dydaktycznego w opisywanej tu perspektywie jest fakt, że nie poprzestaje się na diagnozie trudności w stosunku do osiąganych

${ }^{7}$ Konkretne przykłady zastosowania dialogu dydaktycznego prowadzonego z uczniami z niedoborami języka ojczystego w kontekście nauczania języka obcego, można znaleźć na stronach międzynarodowych projektów Comenius „La gestion mentale - une pédagogie des moyens d'apprendre": www.conaisens.org, realizowanego w latach 2005-2007 oraz realizowanego obecnie projektu „Lire, une recherche active de sens”: www.signesetsens.eu, poświeconego doskonaleniu umiejętności czytania ze zrozumieniem w celu rozwijania kompetencji językowo-komunikacyjnych. 
przez ucznia rezultatów, lecz odnosi się je do przebiegu procesów mentalnych w konstruowaniu pojęć. Błędy użycia są w tej optyce tylko powierzchniowe, niestanowiące o sukcesie w przyswajaniu pojecć (a już tym bardziej o poziomie inteligencji ucznia). Istotne jest wykształcenie umiejętności budowania związków logicznych, nawet jeśli nie prowadzą one od razu do sukcesu komunikacyjnego. Przyjmuje się bowiem, że w sytuacji potrzeby zwrócenia szczególnej uwagi na doskonalenie umiejętności poznawczych, tworzenia pojęć, istotna jest świadomość indywidualnych cech poznawczych sprzyjających tworzeniu reprezentacji przyswajanych treści i rozwijaniu określonych kompetencji. Dialog dydaktyczny umożliwia dokonywanie transferu środków poznawczych, a więc zdolności do uchwycenia zależności logicznych (budowania tych zależności) w danym języku i ich przenoszenia na analogiczne w sytuacje w języku pierwszym.

\section{BIBLIOGRAFIA}

Borowiec, H. 2007. „Kategorie interpretowania rzeczywistości w języku dzieci”. (w) T. Woźniak i A. Domagała (red.). Jezyk, interakcja, zaburzenia mowy. Metodologia badań. Lublin: Wydawnictwo UMCS, seria: Mowa. Teoria - Praktyka. Tom 2/2007, str.: 107-132.

Barth, B. M. 1993. Le savoir en construction. Former à une pédagogie de la compréhension. Paris: Retz.

Buber, M. 1992. Ja i Ty. (przekł. Jan Doktór). Warszawa: Instytut Wydawniczy PAX. str.: 39-126.

Fenille d'IF nr 18 (Revue d'échanges, de réflexions et d'informations autour de la gestion mentale éditée par Initiative et Formation Belgique). 2009. Le dialogue pédagogique, témoignages et réflexions (red. P.-P. Delvaux).

Gaté, J. P. 2000. Les entretiens métacognitifs à visée pédagogique: vers une clinique éducationnelle. (w) Gestion mentale et mobilité de la pensée. Actes du colloque international de Gestion mentale. Rimouski, 14-16 août 2000, str.: 109-133. Karpińska-Szaj, K. 2008. „Nauczyciel języka obcego jako terapeuta mowy”. (w): Jaroszewska, A i M. Lorenc (red.) Kultury i jezyki: poznawać - uczyć sie - nauczać. Ksiega Jubileuszowa dla Pani Profesor Elżbiety Zawadzkiej-Barnik. Warszawa: Wydawnictwo Uniwersytetu Warszawskiego, str.: 61 - 70.

Karpińska-Szaj, K. 2009. "Autour de la compétence d'apprentissage: les pratiques transferogènes pour les élèves en difficulté du langage » (w) Szymankiewicz, K. i J. Zając (red.) Développer les compétences multiples chez. l'enseignant et chez. l'apprenant en classe de langue. Warszawa: Wydawnictwo Uniwersy tetu Warszawskiego - w druku.

Klus-Stańska, D. 2002. Narracje w szkole. (w) J. Trzebiński (red.). Narracja jako sposób rozumienia świata. Gdańsk: Gdańskie Wydawnictwo Psychologiczne, str.: $189-220$.

La Garanderie, A. de 1984. Le dialogue pédagogique avec l'élève. Paris: Le Centurion. 
La Garanderie A. de 2000. "Projet de sens et mouvements ». (w): Actes du Colloque International de Gestion Mentale Gestion mentale et mobilité de la pensée, Rimuski 14-16 août 2000. Paris-Orsay: Institut International de Gestion Mentale, str.: 15-40.

Lewowicki, T. 1977. Indywidualizacja ksz̧tałcenia. Dydaktyka różnicowa. Warszawa: Państwowe Wydawnictwo Naukowe.

Lévesque, J.-Y. 2000. « Gestion mentale, enseignement stratégique et actualisation du potentiel intellectuel: fondement et convergences ». (w): Actes du Colloque International de Gestion Mentale Gestion mentale et mobilité de la pensée, Rimuski 14-16 août 2000. Paris-Orsay: Institut International de Gestion Mentale, str.: 157-192.

Lobocki, M. 2009. Metody i techniki badań pedagogicznych. Kraków: Oficyna Wydawnicza Impuls.

Meirieu, Ph. 2003 [1996]. Frankenstein pédagogue. Paris: ESF éditeur.

Meirieu, Ph. 2004 [1985]. L'école: mode d'emploi - Des «méthodes actives » à la "pédagogie différenciée ». Paris: ESF éditeur.

Nęcka, E. 2003. Inteligencja. Geneza - Struktura - Funk.je. Gdańsk: Gdańskie Wydawnictwo Psychologiczne. Seria: Postępy Psychologii.

Ostrowska, U. 2000. Dialog w pedagogicznym badaniu jakościonym. Kraków: Oficyna Wydawnicza Impuls.

Pawlak, M. 2009. „Metodologia badań nad strategiami uczenia się”. (w): M. Pawlak (red.) Metodologia badań w jezykoznawstwie stosowanym. Neofilolog 32: $65-84$.

Perraudeau, M. 1998. Echanger pour apprendre: l'entretien critique. Paris: Armand Colin.

Stachlewicz, K. 2003. Fenomenologia a dialog. (w): J. Baniak (red.) Filozofia dialogu. Tom 1. Drogi i formy dialogu, str.: 47-59.

Tardif, J. 1999. Le transfert des apprentissages. Montréal: Les Editions Logiques.

Vermersch, P. 1994. L'entretien d'explication. Paris: E.S.F.

Vermersch, P. 1999. "Pour une psychologie phénoménologique ». Psychologie Française 44/1: 7-18.

Wiśniewska, D. 2009. «Dialog jako przestrzeń miedzy badaniem, poznaniem a rozwojem nauczyciela » (w) J. Nijakowska (red.). Jezyk - Poznanie - Zachowanie. Perspektywy $i$ wyzwania w studiach nad proyswajaniem jezyka obcego. Łódź: Wydawnictwo Uniwersytetu Łódzkiego, str.: 283-298.

Wygotski, L. S. 1989 [1966]. Myślenie i mowa. Warszawa: PWN.

http://www.ifbelgique.be/ (DW: 14.10.2009)

http://www.iigm.org/ (DW: 14.10.2009)

http://www.conaisens.org/ (DW: 14.10.2009)

http://www.signesetsens.eu/ (DW: 14.10.2009) 